\title{
Rice Crop Monitoring with Unmanned Helicopter Remote Sensing Images
}

\author{
Kishore C. Swain ${ }^{1}$ and Qamar Uz Zaman ${ }^{2}$ \\ ${ }^{1}$ Department of Agricultural Engineering, \\ Triguna Sen School of Technology, Assam University, \\ ${ }^{2}$ Engineering Department, Nova Scotia Agricultural College, Nova Scotia, \\ India \\ ${ }^{2}$ Canada
}

\section{Introduction}

Agricultural crop, one of the biological entities, is sensitive to its environmental condition including various soil and crop inputs. Alteration in environmental condition causes reduction in crop productivity (such as crop yield and total biomass etc.). Ultra-modern technology such as, precision agriculture (PA) is capable to prevent crop damage and maintain crop productivity. PA is the technology of applying correct amount of crop input at the exact place and time of requirement. Application of PA technology has become increasingly prevalent among the farmers from developed countries as well as developing countries due to its capability for optimizing crop yield by facilitating sound crop status monitoring (Zhang and Taylor, 2001). Mostly, satellite images have been used as the primary source of information for analyzing crop status in precision agriculture. However, obtaining up-to-date aerial photography is very expensive, the quality is variable, and data processing is also intensive and complicated. Innovative new technologies to acquire timely and accurate crop information are required for the success of PA technology.

Assessment of leaf radiation has the potential to detect nitrogen $(\mathrm{N})$ deficiency and is a promising tool for $\mathrm{N}$ management and monitoring. Moreover, over-fertilization may result in surface runoff and pollute subsurface water (Wood et al., 1993; Auernhammer et al., 1999; Daughtry et al., 2000; Zaman et al., 2006). Chlorophyll is an indirect indicator of nitrogen status and is used in optical reflectance-based variable-rate nitrogen application technology (Lee and Searcy, 2000; Jones et al., 2004; Alchanatis et al., 2005; Kim and Reid, 2006; Min et al., 2008). Biermacher et al. (2006) used sensor-based systems to determine crop nitrogen requirements and estimated that the variable-rate system had the potential to achieve a net profit of about $\$ 22$ to $\$ 31$ per ha. The ability to accurately estimate plant chlorophyll concentration can provide growers with valuable information to estimate crop yield potential and to make decisions regarding $\mathrm{N}$ management (Kahabka et al., 2004; Reyniers and Vrindts, 2006; Zaman and Schumann, 2006).

Spectroradiometry has been useful in the research environment for determining principal wavebands and spectral patterns that relate to nutrient stress (Noh et al., 2004; Tumbo et al. 2001). High spectral resolution and the ability to account for temporal changes are distinct 
advantages. Okamoto et al. (2007) used a hyperspectral line-scanning camera for weed detection. This system produced hyperspectral images from a Specim ImSpector V9 imaging spectrograph mounted on a tractor that was set to move slowly through the field. Principal spectral components could be extracted and analyzed using various discrimination schemes. However, on-the-go hyperspectral sensing is slow and impractical, since enough area must be covered per sweep for timely data acquisition over large field areas.

Biomass is an important trait in functional ecology and growth analysis. The typical methods for measuring biomass are destructive, laborious and time consuming. Thus, they do not allow the development of individual plants to be followed and require many individuals to be cultivated for repeated measurements. Non-destructive method may be an option to overcome these limitations. Crop residue estimation has been accomplished using RADARSAT images (Jensen et al., 1990; McNairn et al., 1998), using LANDSAT images (Thoma et al., 2004), and using images captured by radio-controlled model aircraft (Hunt et al., 2005).

Prediction of yield using remote sensing images has been practiced by many researchers (Fablo and Felix, 2001; Alvaro et al., 2007). Rice crop area has been estimated from Landsat images (Tennakoon et al., 1992) for wide-scale yield prediction. Canopy reflectance was estimated at panicle initiation stage using a portable spectroradiometer (LI-1800, LICOR) with a remote cosine receptor attached to a $1.5 \mathrm{~m}$ extension arm for smaller-scale yield prediction (Chang et al., 2005). Yield prediction has also been accomplished for corn (Chang et al., 2003; Kahabka et al., 2004), cotton (Thomasson et al., 2000) wheat (Doraiswamy et al., 2003), citrus (Zaman et al., 2006) and wild blueberry (Zaman et al., 2010). Tea leaf yield was estimated using vegetation indices such as normalized difference vegetation index (NDVI) and triangular vegetation index (TVI) (Rama Rao et al., 2007).

Rice (Oriza sativa L.), which is the staple food of most Asian countries, accounts for more than $40 \%$ of caloric consumption worldwide (IRRI, 2006). Annual rice production was approximately 590 million tons and yield was 4.21 ton ha-1 in Asia for 2006 (FAOSTAT, 2007). The profit from cultivating a rice crop is derived from the crop grain yield and total biomass produced. Predicting rice yield at or around the panicle initiation stage would provide valuable information for future planning and yield expectations.

\section{Low altitude remote sensing (LARS) system}

Site-specific management of inputs characteristic of PA promotes conservation of agricultural resources while maintaining crop viability. However, the application of satellite-based images still cannot fulfill the specific requirements of PA technology. Stafford (2000) observed that satellite images for application of PA are handicapped in terms of spectral and temporal resolution and can be affected by variable weather conditions. Lamb and Brown (2001) indicated that the low-resolution satellite images only beneficial for large-scale studies, are not appropriate for the small-scale farms prevalent in many areas of Asia, for example. Additionally, satellites providing higher-resolution images, e.g., QuickBird (DigitalGlobe, Longmont, Colo.) and ASTER (National Aeronautics and Space Administration, Washington, D.C.), have long revisit times, making them of limited utility for any application that might require frequent images (nutrient stress monitoring, for example). In the past, researchers had used manned aerial vehicles (helicopters and aero planes) to acquire surface images (Table 1). Though a large area can be mapped within short time, cost involved in the aerial vehicles is very high and also requires sophisticated system, trained operators, and professionals. Therefore, an unmanned helicopter is used for aerial image acquisition. 


\begin{tabular}{|l|c|c|c|c|c|c|c|}
\hline \multirow{2}{*}{$\begin{array}{l}\text { Systems/ } \\
\text { Facilities }\end{array}$} & \multicolumn{3}{|c|}{ Equipment } & \multicolumn{4}{c|}{ Applications (size and structure) } \\
\cline { 2 - 8 } & /INS & Laser & Camera & $\begin{array}{c}\text { Large } \\
\text { Areas }\end{array}$ & $\begin{array}{c}\text { Small areas } \\
\left(<2-4 \mathrm{~km}^{2}\right)\end{array}$ & $\begin{array}{c}\text { Route } \\
\text { mapping }\end{array}$ & $\begin{array}{c}\text { Complex } \\
\text { buildings/ } \\
\text { structures }\end{array}$ \\
\hline Aircraft & Yes & Yes & $\begin{array}{c}\text { Film based } \\
\text { and digital }\end{array}$ & Yes & Yes/No & Yes & No \\
\hline Helicopter & Yes & Yes & Digital & No & Yes & Yes & No \\
\hline $\begin{array}{l}\text { Terrestrial } \\
\text { system } \\
\text { (car, train) }\end{array}$ & Yes & Yes & Digital & No & Yes/No & Yes & No \\
\hline $\begin{array}{l}\text { RC- } \\
\text { Helicopter }\end{array}$ & Yes & Yes & Digital & No & Yes & Yes & Yes \\
\hline
\end{tabular}

Table 1. Comparative benefits of remote image acquisition platforms

LARS is a relatively new concept of remote image acquisition currently discussed by agriculturists implementing precision agriculture technology. As the name suggests, it is a system of acquiring images of the earth surface from a lower altitude as compared to the commercial remote sensing satellites. In this system, the images are acquired mostly below cloud cover and very near field features of interest. Low-altitude remote sensing using unmanned aerial vehicles can be an inexpensive and practical substitute for sophisticated satellite and general aviation aircraft, and it is immediately accessible as a tool for the farmer.

Various unmanned LARS systems have been developed and used in the remote image acquisition for PA applications. Some LARS platforms, kites (Aber et al., 2002), balloons (Amoroso and Arrowsmith, 2000; Seang and Mund, 2006), high-clearance tractors (Bausch and Delgado, 2005), and unmanned airplanes and helicopters (Sugiura et al., 2002; Fukagawa et al., 2003; Eisenbiss, 2004; Herwitz et al., 2004; Sugiura et al., 2004; Hunt et al., 2005; MacArthur et al., 2005, 2006; Xiang and Tian, 2006, 2007a, 2007b; Huang et al., 2008) have been successfully using for PA applications in different cropping systems.

These platforms were mounted with image acquisition devices and location measuring receivers, which can fly over agriculture farms and targeted areas for capturing images. As indicated by Sugiura et al. (2002) the major drawbacks of unmanned helicopters are limited payload capacity and precise control over working speed of the system. Thus, mounted systems operation has to be programmed properly to neutralize the effect of wind speed. The low payload capacity of the system was adjusted by selecting light weight mounting equipment and tools. Stombaugh et al. (2003) suggested replacing heavy weight professional digital cameras with light weight, low cost, commercial digital cameras. As the individual images acquired by the LARS system covers small area, geo-referenced images can be mosaic for mapping entire farmland and targeted areas. Global positioning system (GPS) was used in aerial platforms for obtaining aircraft location information (Hayward et al., 1998), for geo-referenced videobased remote sensing images (Thomoson et al., 2002) and in VRT system guidance (Fadel, 2004). Buick (2002) proposed the guidelines to select proper GPS receivers for specific applications. 
Thomson and Sullivan (2006) observed that both agricultural aircraft and unmanned aerial vehicles (UAVs) may potentially more easily scheduled and accessible remote sensing platforms than the remote sensing satellites and general aviation aircraft customarily used in the U.S. However, use of agricultural aircraft is limited to those areas where aerial crop spraying is prevalent. Hunt et al. (2005) used a radio-controlled helicopter-mounted image acquisition system to estimate biomass and nitrogen status for corn, alfalfa, and soybean crops. Digital photographs have been used for site-specific weed control for grassland swards (Gebhardt et al., 2006; Beerwinkle, 2001), for tomato (Zhang et al., 2005) and for wild blueberry (Chang et al., 2011). Chen et al. (2003) using an high-elevation tractor system, indicated that multi-spectral images at 555, 660, and $680 \mathrm{~nm}$ wavelength band centers demonstrated good prediction ability for determining the nitrogen content of rice plants.

This chapter is intended to focus on the effectiveness of low-altitude remote sensing (LARS) images obtained by a multispectral imaging platform mounted in a radio-controlled unmanned helicopter to estimate rice crop parameters as a function of varying nutrient availability. Non-destructive image analysis technique is used to estimate rice yield and total biomass. It also examines the effectiveness of near-real time estimation of protein content from nutrient availability with rice leaf. Consistent with the fact that most multispectral cameras small enough to be used in unmanned aerial vehicles utilize predefined wavebands for feature detection, applicability of the widely used NDVI incorporating these wavebands is evaluated.

\subsection{System components}

A radio-controlled model helicopter (X-Cell Fury 91, Miniature Aircraft, Orlando, USA) is equipped with a Tetracam agricultural digital camera (ADC) (Tetracam, Inc., Chatsworth, Cal.), (Table 2). It is also equipped with various sensors, such as: C-100 Magnetic compass (to obtain platform orientation angle from North), Inertial Measurement Unit (to obtain roll and pitch orientation angles), Barometric sensor (to measure pressure variation for altitude measurement), COM-1288 GPS receiver (to provide position information: latitude and longitude), digital camera (to acquire multispectral (G-R-NIR) images) etc., monitored by a PC-104 based CPU-1232 microprocessor. A PC-104 compatible Power Supply Unit (ACS$5150)$, being powered from an external $12 \mathrm{Vdc}$ battery, is used to supply the necessary power to all the sensors including microprocessor (Figures 1 and 2).

The camera is a wideband multispectral camera utilizing a CMOS CCD (charge-coupled device) with a Bayer filter mask for multispectral imaging (Table 2). The unmanned helicopter weighed about $6 \mathrm{~kg}$ with a payload capacity of $5 \mathrm{~kg}$. The radio console is capable of controlling the unmanned helicopter within a $1 \mathrm{~km}$ radius. The system uses a batteryinitiated glow fuel $(250 \mathrm{~mL})$ engine, supporting $15 \mathrm{~min}$ of flight at length. A spectroradiometer with wavelength range of 350 to $2350 \mathrm{~nm}$ (Spectra Co-op, Inc., Tokyo, Japan) can be used to estimate reflectance at ground level in the red (at $660 \mathrm{~nm}$ ) and NIR bands (at $800 \mathrm{~nm}$ ). Bandwidth at each center is $2.5 \mathrm{~nm}$.

A control program, developed in " $\mathrm{C}$ " programming language, was used for the DOS operating system based microprocessor, to coordinate, the simultaneous clicking of digital camera and obtaining the readings from the sensors, and to store the information as a file in the storing device. The program enabled the system to acquire image and sensor reading at minimum time interval of 12 seconds. The images and corresponding sensor readings as digital number (0-255) were supplied to the image processing algorithm. 


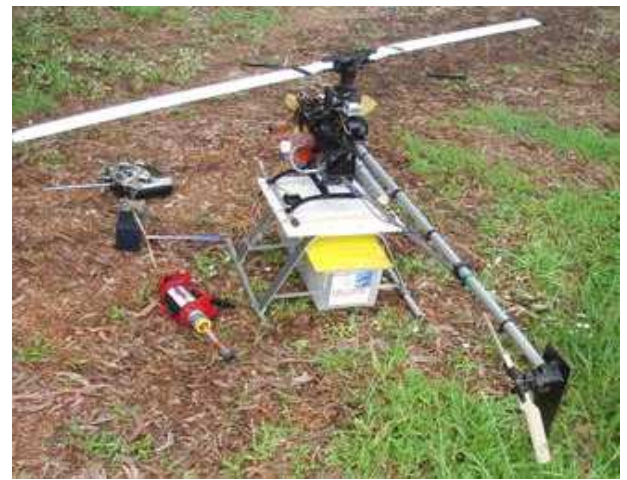

(a)

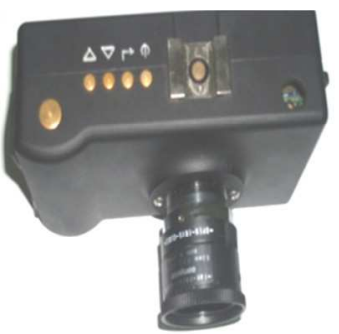

NIR Camera

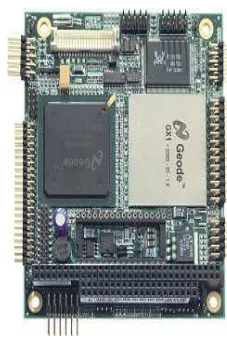

Micro processor

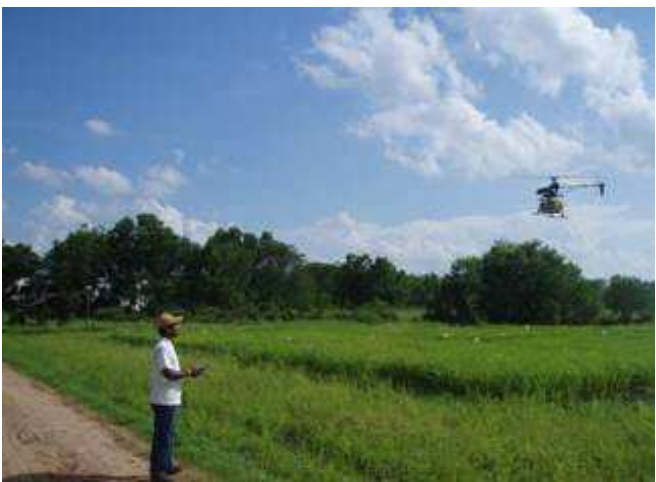

(b)
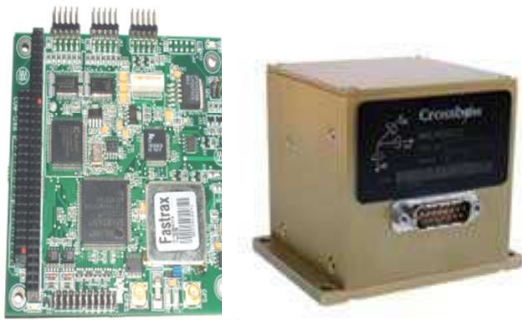

GPS Receiver

(c)

Fig. 1. LARS system operation: (a) R/C helicopter mounted with image acquisition system, (b) acquiring image in rice crop, and c) major components.

\begin{tabular}{|l|l|}
\hline Characteristics & Values \\
\hline Image size (resolution) & $1280 \times 1024$ (1.3 Mpixel) \\
\hline Pixel size & 6.01 micron \\
\hline Ground pixel resolution & $0.000707 \mathrm{~m} /$ pixel (estimated) \\
\hline Spectral bands & $\begin{array}{l}3 \text { (green, red, and NIR); band centers and bandwidths are } \\
\text { fundamentally equivalent to Landsat bands TM2, TM3, and } \\
\text { TM4 }\end{array}$ \\
\hline Lens type & C-mounted \\
\hline Lens & 8.5 mm \\
\hline Triggering & Manual/cable switch triggering \\
\hline
\end{tabular}

Table 2. Specification of the Tetracam ADC Green-Red-NIR sensors 


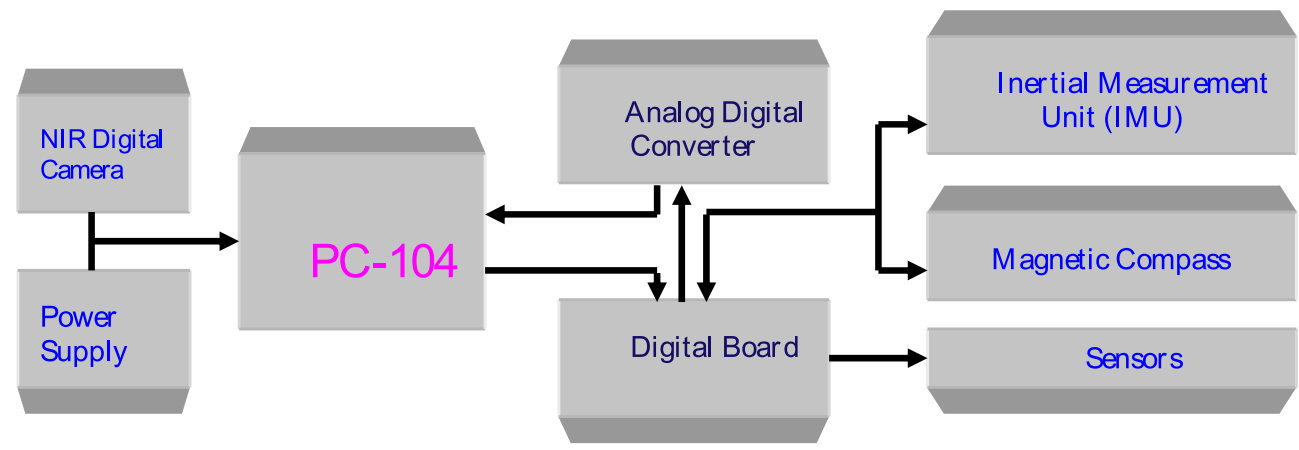

Fig. 2. Schematic representation of the LARS image acquisition system

As individual images, of digital camera covers very small ground area, is mosaic with the algorithm to develop a single map of the study area. HIPSC software converts the digital numbers into relevant sensor readings and used them to carry out image processing operations, such as: image rotation, image mosaic and reflectance index (NDVI, Green NDVI etc.) estimation. The software can develop site-specific zone maps based on variation in reflectance index values and also provide ground control points (GCPs) for mosaic image geo-registration using commercial software.

\subsection{Field preparation and data acquisition}

The experimental site is located in Pathumthani Province, Thailand $\left(14^{\circ} 12^{\prime} \mathrm{N}, 100^{\circ} 37^{\prime} \mathrm{E}\right)$ for the study. The site may be located anywhere in the world, but, the soil properties have to be measured accurately. The soil of the experimental site belonged to the clay textural class with average bulk density of $1.38 \mathrm{~g} \mathrm{~cm}^{-3}$ and $\mathrm{pH}$ of 4.2 . Three replicates were made, and the treatment plots, each of size $10 \mathrm{~m} \times 10 \mathrm{~m}$, randomly distributed within each replicate. To estimate the nitrogen application rate, the total nitrogen present in the soil was tested using standard methods (Kjeldahl apparatus). At the experimental site, the concentration of preexisting nitrogen was classified as low $(<0.18 \%)$ level for all the plots, as per the local Agricultural Extension Service guidelines.

For the underlined experiment, the plots were well-watered using flood irrigation and carefully maintained for pest control to ensure uniform yield potential. The rice seeds were broadcasted (on 14 Dec. 2006) in accordance with local practices under irrigated farming conditions. Nitrogen fertilizer was applied at five rates: $0 \%, 25 \%, 50 \%, 75 \%$, and $100 \%$ of recommended values, representing $0,33,66,99$, and $132 \mathrm{~kg} \mathrm{ha}^{-1}$, respectively. Plots with different nitrogen rates were maintained to promote a wide range of rice yield so the effectiveness of LARS images could be evaluated for varying nutrient availability. This follows a similar technique by Chen et al. (2003), who used four $\mathrm{N}$ rates $(0,45,90$, and $135 \mathrm{~kg} \mathrm{ha}^{-1}$ ) in field experiments with a Tainung 67 rice crop for multispectral image analysis. An early rice variety, Supanburi-1 (95 day period), was used in the study, as this is one of the most popular variety in central Thailand. Urea (46-0-0) was applied as the source of nitrogen for the study. Different nitrogen rates along with recommended phosphorous fertilizer were applied 30 days after sowing rice. Images were obtained twice with the LARS system just before panicle initiation stage ( 45 and 65 days after planting, Figure 1b). 
The altitude has to be selected considering the camera's field of view to acquire a single image for each treatment plot. Images with effective dimensions of $18 \mathrm{~m} \times 14 \mathrm{~m}$ were collected from a $20 \mathrm{~m}$ flying height, covering a single plot. For field application the height can be varied as per the suitability of the researcher, to cover wider area in each image. Flight altitude was recorded with a height sensor (MPXAZ4115A barometric sensor, Freescale Semiconductor, Austin, Tex.) mounted on the LARS system. Images are obtained at five different heights, and the images obtained closest to the $20 \mathrm{~m}$ height were selected for analysis. Five ground-based reflectance readings were obtained for the rice canopy and $\mathrm{BaSO}_{4}$ standard white reference board using the Spectroradiometer in each of the experimental plots. The ground-based readings were obtained immediately after the LARS system-based image acquisition. The plot-wise ground-based reflectance value is calculated as the mean of the five readings.

\subsection{Image pre-processing}

Multispectral images acquired by the Tetracam ADC camera (.dcm format) were converted into .tiff format for analysis. The .tiff format reduces the storage space and also effectively retains the image quality for image processing. Images were uploaded to Pixelwrench software (Tetracam, Inc., Chatsworth, Cal.), which contains programs for deriving one of several vegetation indices (.hdr format) from raw image data. An NDVI image was produced for each test plot, and the average NDVI index was estimated using the customdeveloped program in the $C$ programming language from images acquired by the LARSmounted sensors (Figure 3). Ground-based reflectance data were collected to estimate mean

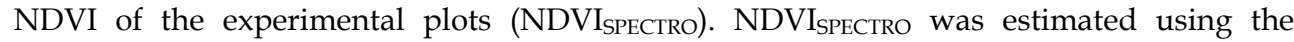
software provided by the Spectroradiometer manufacturer. Linear regression models can be developed in SAS (ver. 9.1, SAS Institute, Inc., Cary, N.C.) or any standard software.

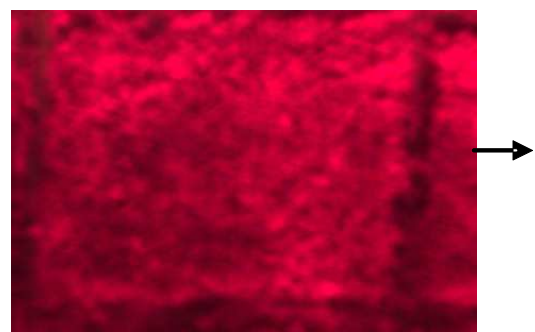

(a)

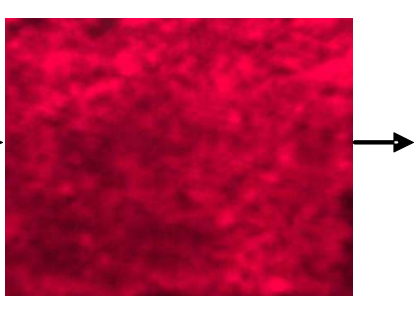

(b)

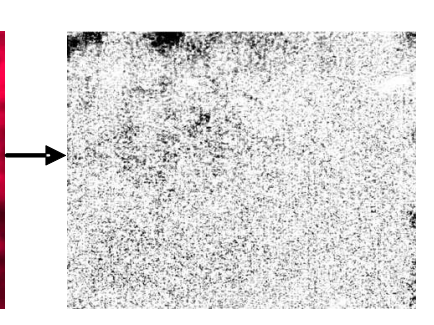

(c)

Fig. 3. Stages of image processing: (a) raw image with plot boundaries (as taken by the image acquisition system), (b) plot-scale image of the rice crop, and (c) NDVI image

\section{Validation of LARS setup}

The normalized difference vegetation index (NDVI) is the mostly adopted reflectance index for agricultural cropping and vegetation studies (Rouse et al., 1973) given as;

$$
N D V I=\frac{N I R-R}{N I R+R}
$$

Where, NIR: Radiance value for Near-infrared band; $R$ : Radiance value for Red band. 
The Green Normalized Differential Vegetation Index (GNDVI) to establish the suitability of reflectance index for rice cropping with variable nitrogen rates (Gitelson et al., 1996) was also used. GNDVI, based on the greenness level, represented by the chlorophyll content determining the radiance level of the leaf surface, was very significant for the rice crop monitoring. The GNDVI was estimated as follows,

$$
G N D V I=\frac{N I R-G}{N I R+G}
$$

Where, NIR: Radiance value for Near-infrared band; G: Radiance value for Green band.

The NDVI index was also calculated from ground level Spectrophotometer radiance values using the Eq ${ }^{\mathrm{n}} .1$ for establishing suitability of LARS system. Around five readings were taken from each plot in order to estimate the average NDVI for each treatment plots. The SPAD 502 meter readings of leaf greenness can be converted into Chlorophyll content by the following equation for rice cropping (Markwell et al., 1995).

\subsection{Relationship between reflectance indices and variable $\mathrm{N}$-treatments}

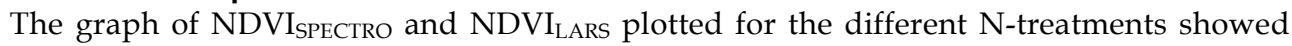
positive response with increased recommended nitrogen rates. The NDVI index, taken 45 days after sowing, showed weak relationship with nitrogen treatment rates, attaining coefficient of determination $\left(\mathrm{r}^{2}\right)$ of 0.60 . As, the fertilizer application, just two weeks before date of testing, response time may not be enough to influence plant leaf radiance level to greater extent (Figure 4$)$. However, the relationship was stronger $\left(\mathrm{r}^{2} \approx 0.85\right)$ with higher NDVI values, ranging from 0.70 to 0.90 , for second set of Spectrophotometer reading taken at booting stage (for 65 days old plants). NDVI LARs, estimated from LARS images, were very low, after 45 days of sowing, ranging from 0.2 to 0.6 , due to the lower radiance value of soil, exposed in gaps between the plants' leaves. The radiance level of the crop leaves, covering the whole plot area with least exposed area at booting stage, attained their original values (with NDVI between 0.85 to 1.0). NDVI $_{\text {LARS }}$ at booting stage showed strong relationship with $\mathrm{r}^{2}$ of 0.73 for different $\mathrm{N}$-treatment rates (Figure $4 \mathrm{~b}$ ). The greenness index (GNDVI) plotted against variable nitrogen rates showed, lower correlation with $\mathrm{r}^{2}$ of 0.66 and 0.7 , for the images taken at 45 days and 65 days respectively, with slightly strong relationship for the later. The lower range of $\mathrm{GNDVI}_{\mathrm{LARS}}$ index had values ranging from 0.5 to 0.6 at booting stage, maintained positive response with higher nitrogen rates (Figure 4c).

\subsection{Suitability of reflectance indices determined from LARS images}

Cross comparison analysis was carried out to testify the applicability of LARS images through indices such as NDVI LARs and GNDVI LARS with the Spectrophotometer reading index such as NDVISPECTRO by plotting graphs between them (Figure 5). The NDVI LARS was proportional to that of NDVISPECTRO with $\mathrm{r}^{2}$ of 0.72 and 0.79 for 45 days and 65 days old rice crop, respectively. The NDVI LARS ranges from 0.85 to 1.0 showing sound crop coverage throughout the plot at booting stage of crop. The lower range $\operatorname{NDVI}_{\text {LARS }}$ value $(0.2 \sim 0.5)$ for 45 days crop made the reading unsuitable to represent the crop in crop modeling and predictions. The higher $\mathrm{r}^{2}$ value $(\approx 0.7)$ for indices estimated from LARS images (NDVI LARS, GNDVI $_{\text {LARS) }}$ with index from ground Spectrophotometer reading (NDVISPECTRO) showed the suitability of the proposed system for crop status studies. 


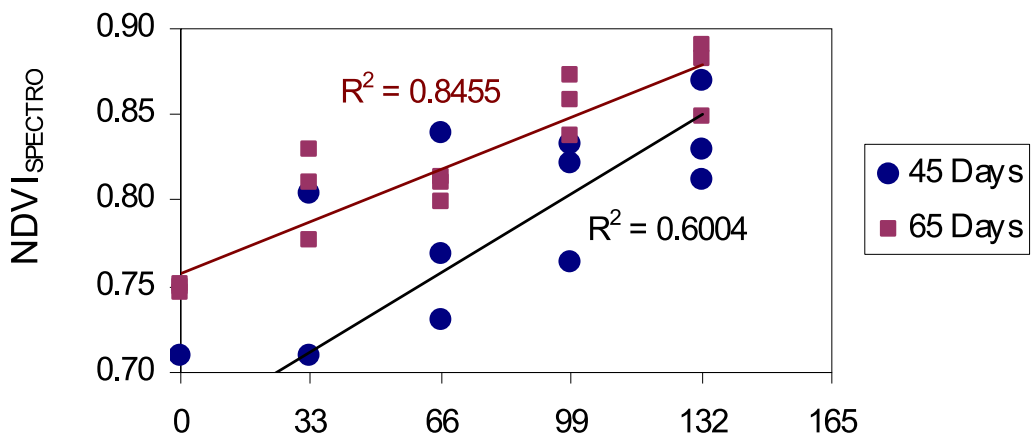

$\mathrm{N}$-treatment rate $\left(\mathrm{kg} \mathrm{ha}^{-1}\right) \quad$ (a)

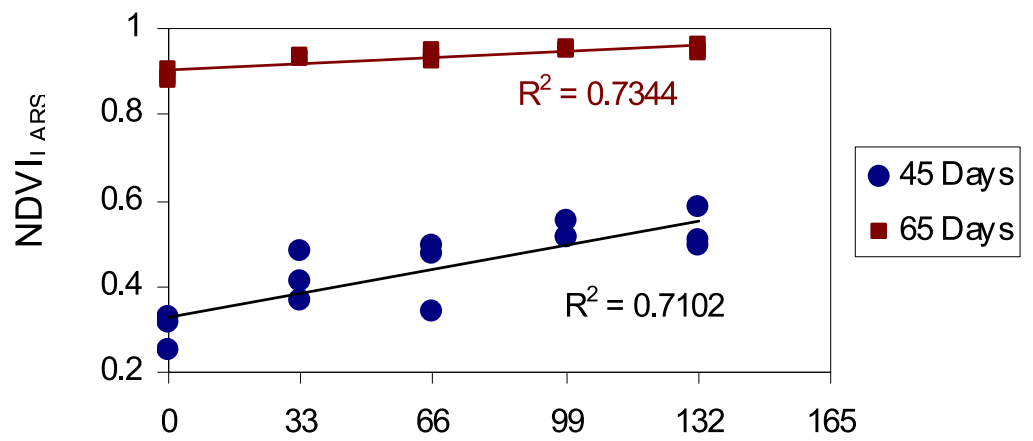

$\mathrm{N}$-treatment rate $\left(\mathrm{kg} \mathrm{ha}^{-1}\right) \quad$ (b)

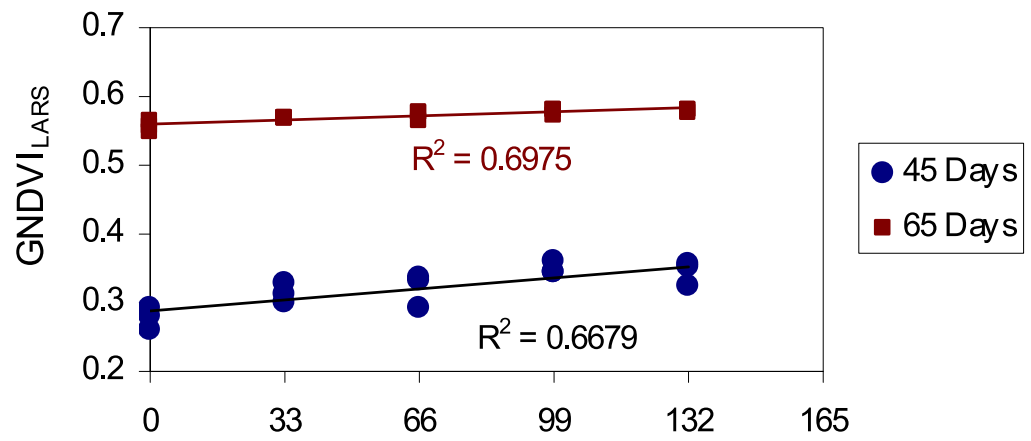

\section{$\mathrm{N}$-treatment rate $\left(\mathrm{kg} \mathrm{ha}^{-1}\right) \quad$ (c)}

Fig. 4. Variation of vegetation index with N-treatment rates; a) NDVI $\mathrm{NPECTRO}_{\text {; }}$ b) $\mathrm{NDVI}_{\mathrm{LARS}} ; \mathrm{c}$ ) GNDVI LARS 

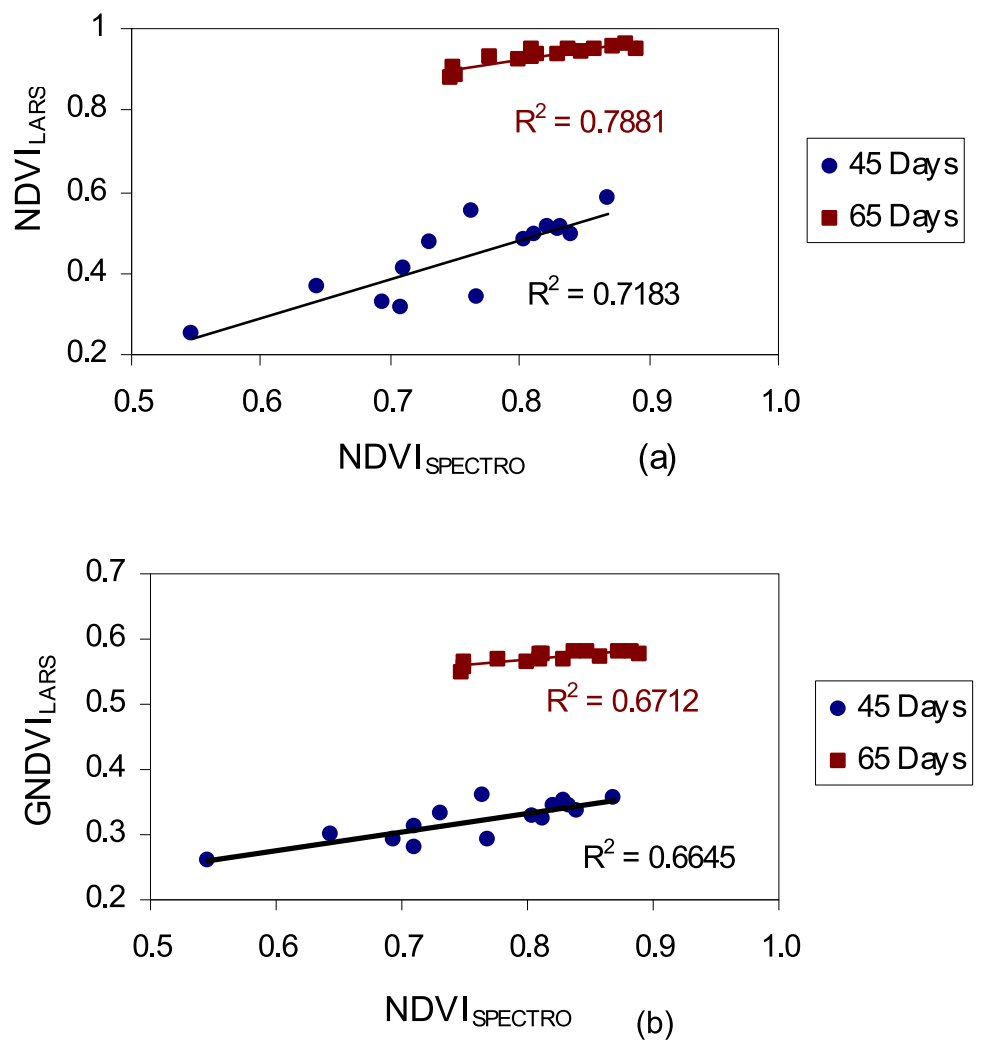

Fig. 5. Comparison of indices based on groundtruthing data and LARS images; NDVISPECTRO with; a) NDVI LARS; b) GNDVI LARS

\subsection{Discussions}

For the experiment, the recommended amount of fertilizer was applied to 40 days old crop and the first set images and groundtruthing were taken at 45 days. The leaf coverage was low with a major share of exposed soil resulting in lower correlation of green indices (NDVI and GNDVI) values. The coefficient of determination $\left(\mathrm{r}^{2}\right)$ was improved visibly for 65 days old crop with denser crop leaving little exposed soil. As observed, 65 days old crop, LARS and ground measurements, was better suited, hence selected for crop status monitoring studies. Variation in green indices (NDVI and GNDVI) showed symmetry with the variation of nitrogen level for different treatments. 


\section{Estimation of crop parameters}

\subsection{Estimation of total biomass}

Biomass is a plant attribute that is time consuming and difficult to measure or estimate, but easy to interpret. Biomass is regarded as an important indicator of ecological and management processes in the vegetation. Biomass estimation facilitates accurate management decisions regarding chemical and fertilizer applications, estimation of yield, and post harvest handling of stover (Pordesimo et al., 2004).Quantifying spatial variation in pasture and crop biomass can help to direct management practices and improve farm productivity, through accurate and informed movements of grazing rotations, crop and pasture nutrient management and also yield prediction (Trotter et al., 2008). Measurement of plant biomass by harvesting is destructive, expensive and time consuming (Reese et al., 1980). de Matthaeis et al. (1995) used AIRSAR data collected over the agricultural fields to monitor biomass variation. They found that the L-band is more effective for crops with low plant density, while C-band is better for high plant density crops.

\subsubsection{Calculations}

The rice biomass (threshed rice plant without the grain) of three sampled areas, $4 \mathrm{~m}^{2}$ each, were collected and weighted. The moisture content (w.b.) of the threshed rice plant was estimated using standard method. The dry weight of the threshed rice plant was estimated and converted into the total biomass weight per ha i.e. (ton/ha).

$$
\text { Total biomass }(\text { ton } / \text { ha })=(100-\text { M.C. }) \times \text { BiomassWt. } \times \frac{10000}{12 \times 1000}
$$

Where,

Total biomass: Weight of rice plant (without rice grain) in ton/ha

BiomassWt: Weight of threshed rice plant (without rice grain)

M.C.: Moisture content of weighed rice plant (w.b.)

Total oven-dried (Abdullah et al., 1992) biomass was ranged from 3.58 to 7.36 ton ha-1 for the different treatments (Table 4). Total dry biomass weight between the treatments showed significant differences at the 0.10 level but no significant difference between replicates.

\begin{tabular}{|l|c|c|c|c|}
\hline \multirow{2}{*}{$\begin{array}{l}\text { N Rate } \\
\text { Treatment }\end{array}$} & \multicolumn{3}{|c|}{ Replicate } & \multirow{2}{*}{ Average } \\
\cline { 2 - 4 } & 1 & 2 & 3 & \\
\hline $0 \mathrm{~kg} \mathrm{ha}^{-1}$ & 3.58 & 4.25 & 6.30 & 4.710 \\
\hline $33 \mathrm{~kg} \mathrm{ha}^{-1}$ & 5.51 & 5.84 & 5.64 & 5.660 \\
\hline $66 \mathrm{~kg} \mathrm{ha}^{-1}$ & 5.57 & 5.97 & 5.77 & 5.771 \\
\hline $99 \mathrm{~kg} \mathrm{ha}^{-1}$ & 6.50 & 7.36 & 5.97 & 6.611 \\
\hline $132 \mathrm{~kg} \mathrm{ha}^{-1}$ & 5.57 & 6.63 & 7.30 & 6.501 \\
\hline
\end{tabular}

Table 3. Total biomass (ton ha-1) of the experimental plots

Linear calibrations curves were developed in SAS 9.1 to estimate the biomass from NDVI index values calculated from LARS images. From these results, $\mathrm{NDVI}_{\mathrm{LARS}}$ could explain $76 \%$ of the variation in biomass weight $\left(r^{2}=0.760\right.$, RMSE $=0.598$ ton ha-1, Figure 6$)$. 


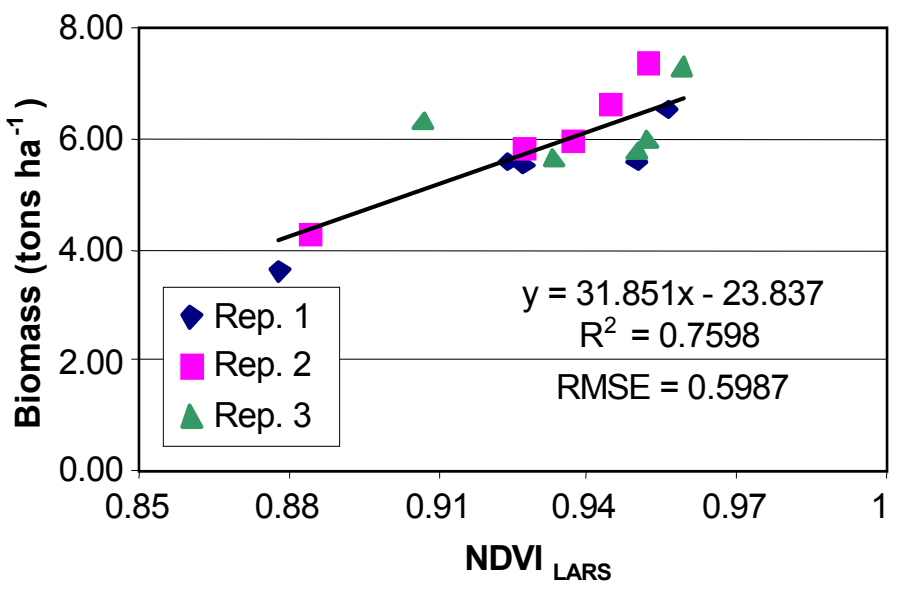

Fig. 6. Estimation of biomass with NDVI $_{\text {LARS values }}$

\subsection{Estimation of rice yield}

The rice crop was harvested from three sample areas of $4 \mathrm{~m}^{2}$ from each plot, 102 days after sowing for this experiment. The moisture content (\% w.b.) at the time of weighing was estimated using a field moisture meter (Kett PM600, Ohta-Ku, Tokyo, Japan). The yield of each plot $\left(100 \mathrm{~m}^{2}\right.$ area) was estimated as the average of three sampled areas and converted to a ton-per-hectare area using the following equation. Rice yield was estimated at $14 \%$ moisture content (MC) for each treatment (Field crop report, 1998).

$$
\text { Yield }\left(\text { ton } h a^{-1}\right)=\frac{(100-M C) \times R W \times 10000}{86 \times A \times 1000}
$$

Where,

$\mathrm{MC}=$ moisture content $(\%$ wet basis $)$

$\mathrm{RW}=$ weight of rice $(\mathrm{kg})$

$\mathrm{A}=$ harvested area $\left(\mathrm{m}^{2}\right)$

Rice yield, ranged from as low as 1.88 ton ha-1 $\left(0 \mathrm{~kg} \mathrm{ha}^{-1} \mathrm{~N}\right)$ to 3.68 ton ha-1 $\left(132 \mathrm{~kg} \mathrm{ha}^{-1} \mathrm{~N}\right)$ based on a $14 \% \mathrm{MC}$, illustrates the effectiveness of the fertilizer treatment rates on rice yield (Table 4). The crop yield variation was also tested for statistical significance (Johnson and Bhattacharyya, 2001). Yield data between the treatments showed significant differences at the 0.10 and 0.05 levels, whereas differences were not significant among the replicates

\begin{tabular}{|l|c|c|c|c|}
\hline \multirow{2}{*}{$\begin{array}{l}\text { N Rate } \\
\text { Treatment }\end{array}$} & \multicolumn{3}{|c|}{ Replicate } & \multirow{2}{*}{ Average } \\
\cline { 2 - 4 } & 1 & 2 & 3 & \\
\hline $0 \mathrm{~kg} \mathrm{ha}^{-1}$ & 1.88 & 1.97 & 1.64 & 1.83 \\
\hline $33 \mathrm{~kg} \mathrm{ha}^{-1}$ & 2.13 & 2.87 & 3.28 & 2.76 \\
\hline $66 \mathrm{~kg} \mathrm{ha}^{-1}$ & 2.78 & 2.70 & 3.44 & 2.97 \\
\hline $99 \mathrm{~kg} \mathrm{ha}^{-1}$ & 2.37 & 3.85 & 3.52 & 3.25 \\
\hline $132 \mathrm{~kg} \mathrm{ha}^{-1}$ & 3.52 & 3.36 & 3.68 & 3.52 \\
\hline
\end{tabular}

Table 4. Rice yield (ton ha-1) of the experimental plots 
The regression model, developed for rice yield with NDVI index value in SAS 9.1, indicated a good fit $\left(\mathrm{r}^{2}=0.728, \mathrm{RMSE}=0.458\right.$ ton ha-1, Figure 7$)$. Variation among the replicates might be due to initial nutrient levels present in the soil from randomly selected plots.

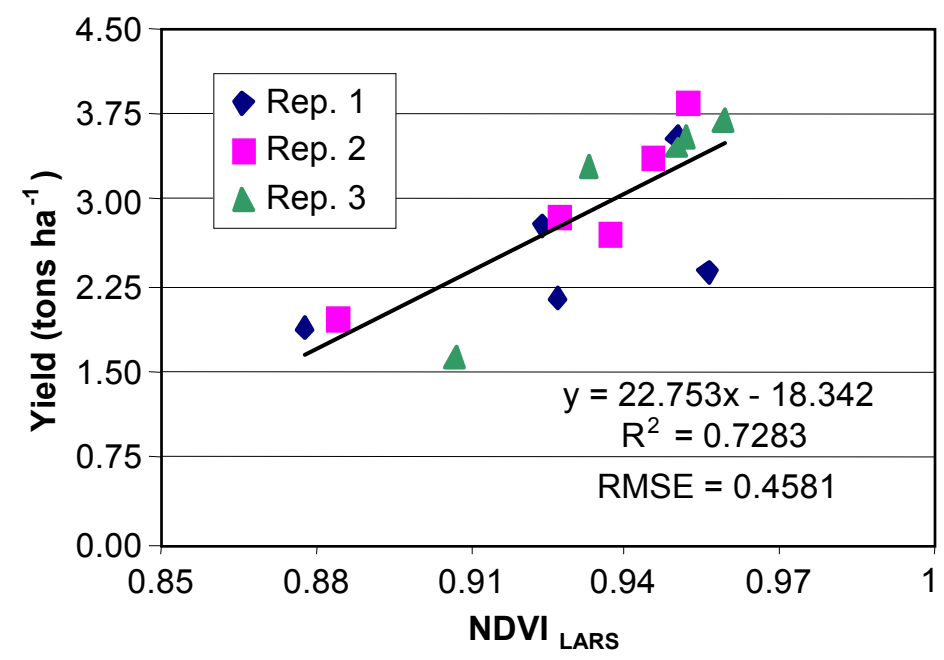

Fig. 7. Estimation of rice yield with NDVI $_{\text {LARS values. }}$

\subsection{Estimation of protein content}

Protein content is one of the major food nutrients to determine quality of the food-grain. It could be measured as the total available nitrogen content in the food stuff (Kennedy, 1995). The rice was powdered and sieved before testing for total nitrogen with standard method. The linear model of total nitrogen against NDVI LARS (with $r^{2}=0.591$, Figure 8 ) showed positive relationships, and would be useful to the farmers, as they can get idea of quality of rice grain well in advance, at booting stage (from the image taken during booting stage).

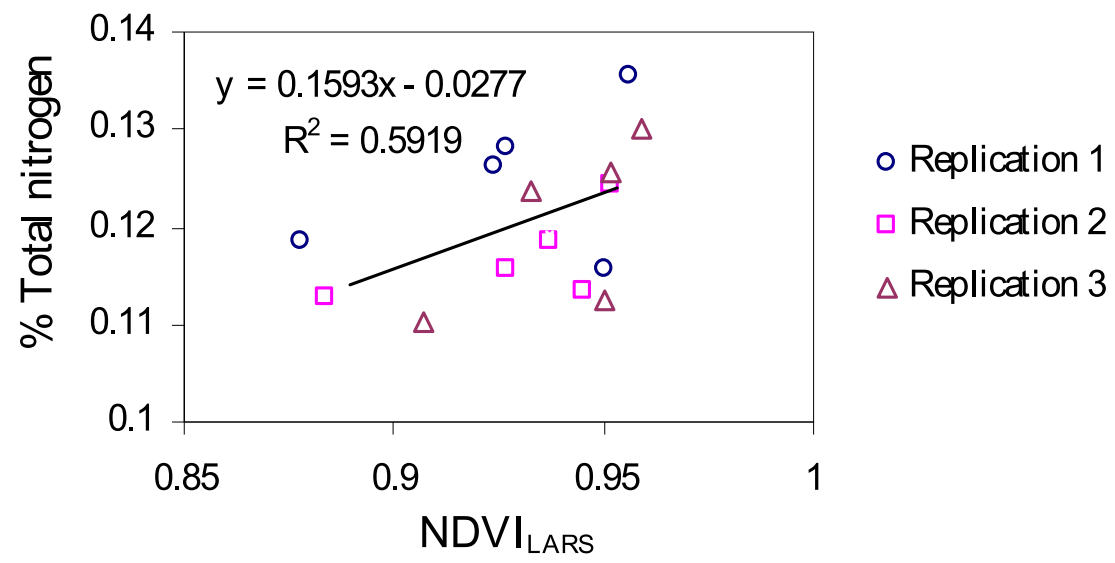

Fig. 8. Estimation of protein content with NDVI LARS values. 


\subsection{Discussions}

The NDVI value, calculated from the LARS images collected for 65 days old crop, was suitable to estimate the total biomass $(\mathrm{r} 2=0.760)$ and rice crop yield $(\mathrm{r} 2=0.728)$. The protein content estimated through NDVI value was marginally suitable, capable to provide overall rice crop quality before-hand. The LARS system is suitable for real and near-real time crop parameter estimation, monitoring and evaluations. The NIR sensors can be substituted with any professional camera or cheap digital camera to optimize cost involved. The overall efficiency of the LARS system will be dependent on the sensors mounted on the helicopter. A skilled labor can easily handle the whole system with least supervision. The LARS not only replaces the satellite based image processing system but also ground level spectrophotometer, chlorophyll content measuring equipments. With little time, the system will be ready for taking images, for instance, just after rainfall.

\section{Field application of LARS systems}

Sugiura et al. (2007) mounted a thermal band camera on unmanned helicopter platform to estimate soil water status in paddy fields and correlation was obtained between the thermal image temperature and soil moisture content. The coefficient of determination $\left(\mathrm{r}^{2}\right)$ for moisture content and temperature model at 10.00 a.m. and 3.00 p.m. were 0.69 and 0.64 respectively (Figure 9).

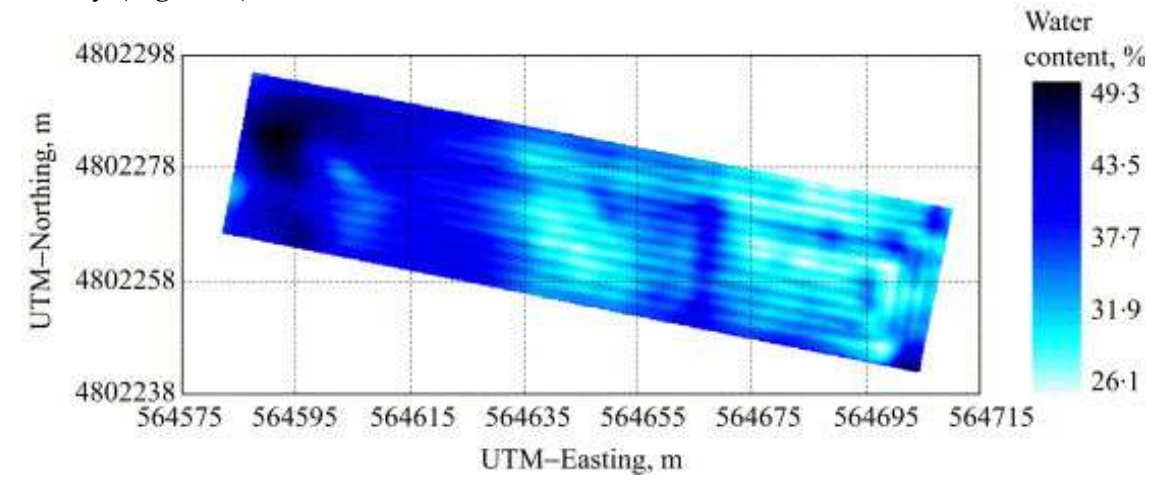

Fig. 9. Soil moisture content estimation with LARS images (Sugiura et al., 2007)

The $\mathrm{r}^{2}$ between moisture content and difference in temperature was $0 \cdot 42$. The development was intended assisting in proper irrigation scheduling and monitoring water stressed situations for rain-fed cropping. Ishii et al. (2005) developed a system that can generate a map regarding crop status obtained by mounting an imaging sensor on an unmanned helicopter. They achieved an accuracy of $38 \mathrm{~cm}$ using RTK GPS receiver and GDS unit. The maps are accurate enough to be used for variable rate nutrients and pesticides application for the farmland.

Lenthe et al. (2007) used unmanned helicopter based IR thermography imaging system as a tool for monitoring the microclimatic conditions promoting incidence and severity of diseases within wheat fields with a high spatial resolution. Zhou et al. (2009) used R44 helicopter for aerial electrostatic spraying system. The results of the studies showed that electrostatic spraying with helicopters could produce uniform and fine droplets with better droplet adhesion and distribution, higher depositing efficiency, lower environmental 
contamination; lower pesticide application rate and aerial spray can improve efficiency for prevention and cure pests in agriculture and forestry.

\section{Conclusions}

A radio-controlled helicopter-based LARS system can be used to acquire multispectral images over a rice canopy to estimate rice yield. The study indicated that the LARS platform could substitute for satellite-based and costly airborne remote sensing system. Images are obtained successfully by the multispectral camera mounted on the radio-controlled helicopter at a height of $20 \mathrm{~m}$ over rice plots. Rice yield and total biomass were found to be significantly different at the 0.05 and 0.1 significance levels, respectively, under different $\mathrm{N}$ treatment regimes. The relationship between NDVI LARS and NDVISPECTRO $\left(\mathrm{r}^{2}=0.897\right.$, RMSE $=0.012$ ) shows the applicability of LARS sensor-based images for estimating NDVI values, which varied over the five levels of applied N. A linear regression model shows a good fit $\left(\mathrm{r}^{2}=0.728\right.$, RMSE $=0.458$ ton $\left.\mathrm{ha}^{-1}\right)$ for estimating total biomass for rice using LARS imagebased NDVI values. A linear model $\left(\mathrm{r}^{2}=0.760\right.$, RMSE $=0.598$ ton $\left.\mathrm{ha}^{-1}\right)$ indicates that rice yield could also be predicted with NDVI values derived from LARS images. The protein content can be positively estimated well in advance to actual crop harvesting. The regression model procedure outlined herein can be followed for larger rice fields by recording crop input rates and acquiring LARS images.

\section{References}

Abdullah, N., Y. W. Ho, and S. Jalaludin. 1992. Microbial colonization and digestion of feed materials in cattle and buffaloes: II. Rice straw and palm press fibre. AsianAustralasian J. Animal Sci. 5(2): 329-335.

Aber, J. S., K. Aaviksoo, E. Karofeld, and S. W. Aber. 2002. Patterns in Estonian bogs as depicted in color kite aerial photographs. Suo (Mires and Peat) 53(1): 1-15.

Alchanatis, V., Z. Schmilovitch, and M. Meron. 2005. In-field assessment of single-leaf nitrogen status by spectral reflectance measurements. Precision Agric. 6(1): 25-39.

Alvaro, F., L. F. García del Moral, and C. Royo. 2007. Usefulness of remote sensing for the assessment of growth traits in individual cereal plants grown in the field. Intl. J. Remote Sensing 28(11): 2497-2512.

Amoroso, L., and R. Arrowsmith. 2000. Balloon photography of brush fire scars east of Carefree, Arizona. Tempe, Ariz.: Arizona State University, Department of Geological Sciences.

Auernhammer, H., M. Demmel, F. X. Maidl, U. Shmidnalter, T. Schneider, and P. Wagner. 1999. An on-farm communication system for precision farming with nitrogen realtime application. ASAE Paper No. 991150. St. Joseph, Mich.: ASAE.

Buick, R. 2002. GPS guidance: Making an informed decision. In Proc. of 6th International Conference on Precision Agriculture 1979-2004. CD-ROM, P.C.Robert et al. Madison, Wisc, ASA, CSSA, and SSA.

Bausch, W., and J. A. Delgado. 2005. Impact of residual soil nitrate on in-season nitrogen applications to irrigated corn based on remotely sensed assessments of crop nitrogen status. Precision Agric. 6(6): 509-519.

Beerwinkle, K. R. 2001. An automatic capture-detection, time-logging instrumentation system for boll weevil pheromone traps. Applied Eng. in Agric. 17(6): 893-898. 
Biermacher, J. T., F. M. Epplin, B. W. Brorsen, J. B. Solie, and W. R. Raun. 2006. Maximum benefit of a precise nitrogen application system for wheat. Precision Agric. 7(3): 193204.

Chang, J., D. E. Clay, K. Dalsted, S. Clay, and M. O'Neill. 2003. Corn (Zea mays L.) yield prediction using multispectral and multidate reflectance. Agron. J. 95(6): 1447-1453.

Chang, K. W., Y. Shen, and J. C. Lo. 2005. Predicting rice yield using canopy reflectance measured at booting stage. Agronomy Journal, 97(3): 872-878.

Chang, Y. K., Q. U. Zaman, A. W. Schumann, and D. C. Percival. 2011. Performance tests of g-ratio index and color co-occurrence matrix based machine vision algorithms in the wild blueberry fields. ASABE Paper No 09558 (ASAE, St. Joseph, MI, USA)

Chen, S., C. W. Huang, C. C. Huang, C. K. Yang, T. H Wu, Y. Z. Tsai, and P. L. Miao. 2003. Determination of nitrogen content in rice crop using multi-spectral imaging. ASAE Paper No. 031132. St. Joseph, Mich.: ASAE.Daughtry, C. S. T., C. L. Walthall, M. S. Kim, E. B. de Colstoun, and J. E. McMurtrey III. 2000. Estimating corn leaf chlorophyll concentration from leaf and canopy reflectance. Remote Sensing of Environment, 74(2): 229-23.

de Matthaeis, P., P. Ferrazzoli, G. Schiavon and D. Solimini.1995. Crop type identification and biomass estimation by SAR. Geoscience and Remote Sensing Symposium, 1995. IGARSS '95. 'Quantitative Remote Sensing for Science and Applications', International.

Doraiswamy, P. C., S. Moulin, P. W. Cook, and A. Stern. 2003. Crop yield assessment from remote sensing. Photogram. Eng. and Remote Sensing, 69(6): 665-674.

Eisenbiss, H. 2004. A mini unmanned aerial vehicle (UAV): System overview and image acquisition. In Proc. Intl. Workshop on Processing and Visualization Using HighResolution Imagery. International Society for Photogrammetry and Remote Sensing (ISPRS).

Fablo, M., and R. Felix. 2001. Analysis of GAC NDVI data for cropland identification and yield forecasting in Mediterranean African countries. Photogram. Eng. and Remote Sensing 67(5): 593-602.

FAOSTAT. 2007. Agricultural Statistics Yearbook: 2006. Rome, Italy: Food and Agriculture Organization of the United Nations.Fadel, M. 2004. Performance assessment of VRT-based granular fertilizer broadcasting systems. Agricultural Engineering International: the CIGR Journal of Scientific Research and Development, Manuscript PM 03 001, Vol.6.Field crop report. 1998. Field crop report for rice cropping in Thailand. Bangkok, Thailand: Field Crop Research Station.

Fukagawa, T., K. Ishii, N. Noguchi, and H. Terao. 2003. Detecting crop growth by a multispectral imaging sensor. ASAE Paper No. 033125. St. Joseph, Mich.: ASAE.

Gebhardt, S., J. Schellberg, R. Lock, and W. Kuhbauch. 2006. Identification of broad-leaved dock (Rumex obtusifolius L.) on grassland by means of digital image processing. Precision Agriculture, 7(3): 165-178.

Gitelson, A. A., Y. J. Kaufman and M. N. Merzlyak. 1996. Use of a green channel in remote sensing of global vegetation from EOS-MODIS, Rem. Sens. Environ., 58: 289-298.

Hayward, R. C., D. Gebre-Egziabher, and J. D. Powell. 1998. GPS based attitude for aircraft: www. waas. standford.edu. 
Herwitz, S. R., L. F. Johnson, S. E. Dunagan, and R. G. Higgins. 2004. Imaging from an unmanned aerial vehicle: Agricultural surveillance and decision support. Computers and Electronics in Agric. 44(1): 49-61.

Huang, Y., Y. Lan, W. C. Hoffmann, and B. Fritz. 2008. Development of an unmanned aerial vehicle-based remote sensing system for site-specific management in precision agriculture. In Proc. 9th Intl. Conf. on Precision Agriculture. Denver, Colo.: Colorado State University.

Hunt, E. R., C. L. Walthall, and C. S. T. Daughtry. 2005. High-resolution multispectral digital photography using unmanned airborne vehicles. In Proc. 20th Biennial Workshop on Aerial Photography, Videography, and High-Resolution Digital Imagery for Resource Assessment. Bethesda, Md.: American Society for Photogrammetry and Remote Sensing (ASPRS).

IRRI. 2006. Atlas of Rice and World Rice Statistics. Manila, Philippines: International Rice Research Institute.

Ishii, K., N., Noguchi and R. Sugiura. 2005. Remote-sensing technology for vegetation monitoring using an unmanned helicopter, Biosystems Engineering, 90 (4), 369379 .

Jensen, A., B. Lorenzen, H. Spelling-Ostergaard, and E. Kloster-Hvelplund. 1990. Radiometric estimation of biomass and $\mathrm{N}$ content of barley grown at different $\mathrm{N}$ levels. Intl. J. Remote Sensing 11(10): 1809-1820.

Johnson, R. A., and G. K. Bhattacharyya. 2001. Statistics: Principles and Methods. 4th ed. John Wiley and Sons.

Jones, C. L., N. O. Maness, M. L. Stone, and R. Jayasekara. 2004. Chlorophyll estimation using multi-spectral reflectance and height sensing. ASAE/CSAE Paper No. 043081. St. Joseph, Mich.: ASAE.

Kahabka, J. E., H. M. V. Es, E. J. McClenahan, and W. J. Cox. 2004. Spatial analysis of maize response to nitrogen fertilizer in central New York. Precision Agric. 5(5): 463-476.

Kennedy, P. M. 1995. Intake and digestion in swamp buffaloes and cattle: 3. Comparison with four forage diets, and with rice straw supplemented with energy and protein. J. Agric. Sci. Cambridge 124(2): 265-275.

Kim, Y., and J. F. Reid. 2006. Modeling and calibration of a multi-spectral imaging sensor for in-field crop nitrogen assessment. Applied Eng. in Agric. 22(6): 935-941.

Lamb, D. W., and R. B. Brown. 2001. Remote sensing and mapping of weeds in crops. J. Agric. Eng. Res. 78(2): 117-125.

Lee, W. S., and S. Searcy. 2000. Multispectral sensor for detecting nitrogen in corn plants. ASAE Paper No. 001010. St. Joseph, Mich.: ASAE.

Lee, Y. S., C. M. Yang, and A. H. Chang. 2002. Changes of nitrogen and chlorophyll contents and reflectance spectral characteristics to the application of nitrogen fertilizer in rice plants. J. Agric. Res. China, 51(1): 1-14.

Lenthe, J.H., E.C. Oerke and H.W. Dehne. 2007. Digital infrared thermography for monitoring canopy health of wheat. Precision Agriculture, 8(1):15-26.

MacArthur, D., J. K. Schueller, and C. D. Crane. 2005. Remotely piloted mini-helicopter imaging of citrus. ASAE Paper No. 051055. St. Joseph, Mich.: ASABE. 
MacArthur, D., J. K. Schueller, W. S. Lee, C. D. Crane, E. Z. MacArthur, and L. R. Parsons. 2006. Remotely piloted helicopter citrus yield map estimation. ASABE Paper No. 063096. St. Joseph, Mich.: ASABE.

McNairn, H., D. Wood, Q. H. J. Gwyn, R. J. Brown, and F. Charbonneau. 1998. Mapping tillage and crop residue management practices with RADARSAT. Canadian J. Remote Sensing 24(1): 110-115.

Min, M., W. S. Lee, T. F. Burks, J. D. Jordan, A. W. Schumann, J. K. Schueller, and H. Xie. 2008. Design of a hyperspectral nitrogen sensing system for orange leaves. Computers and Electronics in Agric. 63(2): 215-226.

Markwell, J., J. C. Osterman, and J. L. Mitchell. 1995. Calibration of the Minolta SPAD-502 leaf chlorophyll meter", Photosynth. Res., 46, 467-472.

Noh, H. K., Q. Zhang, and S. Han. 2004. Sensor-based variable-rate application of nitrogen by using multi-spectral image sensor. ASAE Paper No. 041133. St. Joseph, Mich.: ASAE.

Okamoto, H., T. Murata, T. Kataoka, and S-I Hata. 2007. Plant classification for weed detection using hyperspectral imaging with wavelet analysis. Weed Biol. and Mgmt. 7(1): 31-37.Pordesimo, L.O., W.C. Edens, and S. Sokhansanj. 2004. Distribution of aboveground biomass in corn stover. Biomass and Bioenergy 26:337-343.

Rama Rao, N., M. Kapoor, N. Sharma, and K. Venkateswarlu. 2007. Yield prediction and waterlogging assessment for tea plantation land using satellite image-based techniques. Intl. J. Remote Sensing 28(7): 1561-1576.

Reese, G.A., R.L. Bayn, and N.E. West. 1980. Evaluation of double-sampling estimators of subalpine herbage production. Journal of Range Management 33:300-306.

Reyniers, M., and E. Vrindts. 2006. Measuring wheat nitrogen status from space and ground-based platform. Intl. J. Remote Sensing 27(3): 549-567.

Rouse, J. W., R. H. Haas, J. A. Shell, and D. W. Deering. 1973. Monitoring vegetation systems in the Great Plains with ERTS-1. In Proc. 3rd Earth Resources Technology Satellite Symp., 1: 309-317. NASA SP-351. Washington, D.C.: NASA.

Seang, T. P. and J-P Mund. 2006. Geo-referenced balloon digital aerial photo technique: A low-cost high-resolution option for developing countries. In Proc. Map Asia 2006: 5th Annual Conf. on Geographic Information Technology and Application. GIS Development Pvt. Ltd., Noida, India.

Stafford, J. V. 2000. Implementing precision agriculture in the 21st century. J. Agric. Eng. Res. 76(3): 267-275.

Stombaugh, T., A. Simpson, J. Jacobs and T. Mueller. 2003. A low cost platform for obtaining remote sensed imagery. In: Precision Agriculture, Edited by J. Stafford and A. Werner, pp.665-676.

Sugiura, R., N. Noguchi, K. Ishii, and H. Terao. 2002. The development of remote sensing system using unmanned helicopter. In Proc. Automation Technology for Off-Road Equipment, 120-128. ASAE Paper No. 701P0502. Q. Zhang, ed. St. Joseph, Mich.: ASAE.

Sugiura, R., K. Ishii, and N. Noguchi. 2004. Remote sensing technology for field information using an unmanned helicopter. In Proc. Automation Technology for Off-Road Equipment. ASAE Paper No. 701P1004. St. Joseph, Mich.: ASAE.Sujiura, R., N. Naguchi and K. Ishii. 2007. Correction of low-altitude thermal images applied to estimating of soil water status, Biosystems Engineering, 96(3), 301-313. 
Tennakoon, S. B., V. V. N. Murty, and A. Eiumnoh. 1992. Estimation of cropped area and grain yield of rice using remote sensing data. Intl. J. Remote Sensing 13(3): 427-439.

Thoma, D., S. Gupta, and M. Bauer. 2004. Evaluation of optical remote sensing models for crop residue cover assessment. J. Soil and Water Cons. Soc. 59(5): 224-233.

Thomasson, J. A., R. Sui, and D. C. Akins. 2000. Spectral changes in picked cotton leaves with time. In: Proc. $5^{\text {th }}$ Intl. Conf. on Precision Agriculture $\mathcal{E}$ Other Resources Mgmt. Ames, Iowa: USA.

Thomoson, S. J., J. E., Hanks, and G. F. Sassenrath-Cole. 2002. Continuous georeferencing for video-based remote sensing on agricultural air craft. Trans. of ASAE, 45(40): 11771189.

Thomson, S. J., and D. G. Sullivan. 2006. Crop status monitoring using multispectral and thermal imaging systems for accessible aerial platforms. ASABE Paper No. 061179. St. Joseph, Mich.: ASABE.

Trotter, T. F., P.S. Frazier, M. G. Trotter and D. W. Lamb. 2008. Objective biomass assessment using and active plant sensor (crop circle)- Preliminary experience on a variety of agricultural landscapes, Report from Precision Agriculture Research Group, The University of New England, Australia.

Tumbo, S. D., D. G. Wagner, and P. H. Heinemann. 2001. On-the-go sensing of chlorophyll status in corn. ASAE Paper No. 011175. St. Joseph, Mich.: ASAE.

Wood, C. W., D. W. Reeves, and D. G. Himelrick. 1993. Relationships between chlorophyll meter readings and leaf chlorophyll concentration, $\mathrm{N}$ status, and crop yield: A review. Proc Agron. Soc. New Zealand 23: 1-9.

Xiang, H., and L. Tian. 2006. Development of autonomous unmanned helicopter-based agricultural remote sensing system. ASABE Paper No. 063097. St. Joseph, Mich.: ASABE.

Xiang, H., and L. Tian. 2007a. An autonomous helicopter system for aerial image collection. ASABE Paper No. 071136. St. Joseph, Mich.: ASABE.

Xiang, H., and L. Tian. 2007b. Autonomous aerial image georeferencing for an UAV-based data collection platform using integrated navigation system. ASABE Paper No. 073046. St. Joseph, Mich.: ASABE.

Zaman, Q. U., K. C. Swain, A. W. Schumann, and D. C. Percival. 2010. Automated, lowcostyield mapping of wild blueberry fruit. Applied Engineering in Agriculture. 26(2): 225-232.

Zaman, Q. U., A. W. Schumann, and S. Shibusawa. 2006. Impact of variable rate fertilizationon nitrate leaching in citrus orchards. $8^{\text {th }}$ Int. Precision Agriculture Conf. Minnesota. July 24-26, 2006.

Zaman, Q., A. W. Schumann, and K. H. Hostler. 2006. Estimation of citrus fruit yield usingultrasonically sensed tree size. Applied Eng. in Agric. 22(1): 39-44.Zaman, Q. U., and A. W. Schumann. 2006. Nutrient management zones for citrus based on variation in soil properties and tree performance. Precision Agriculture 7(1):4563.

Zhang, F., B. Wu, and C. Liu. 2003. Using time series of SPOT VGT NDVI for yield forecasting. In Proc. Geoscience and Remote Sensing Symp., 1: 386-388. Piscataway, N.J.: IEEE. 
Zhang, M., Z. Qin, and X. Liu. 2005. Remote sensed spectral imagery to detect late blight in field tomatoes. Precision Agric. 6(6): 489-508.

Zhang, N., and R. K. Taylor. 2001. Applications of a field-level geographic information system (FIS) in precision agriculture. Applied Eng. in Agric. 17(6): 885-892.

Zhou, H., Y. Ru, C. Shu, J. Zheng, and H. Zhu. 2009. Design and experiments of aerial electrostatic spraying system assembled in helicopter. ASABE Paper No. 097378, Annual Meeting at Reno, Nevada, June 21-24. 


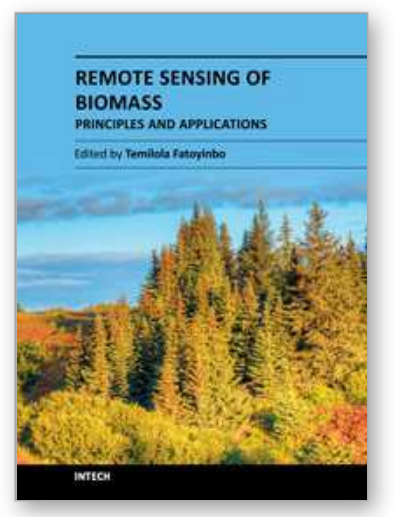

\author{
Remote Sensing of Biomass - Principles and Applications \\ Edited by Dr. Lola Fatoyinbo
}

ISBN 978-953-51-0313-4

Hard cover, 322 pages

Publisher InTech

Published online 28, March, 2012

Published in print edition March, 2012

The accurate measurement of ecosystem biomass is of great importance in scientific, resource management and energy sectors. In particular, biomass is a direct measurement of carbon storage within an ecosystem and of great importance for carbon cycle science and carbon emission mitigation. Remote Sensing is the most accurate tool for global biomass measurements because of the ability to measure large areas. Current biomass estimates are derived primarily from ground-based samples, as compiled and reported in inventories and ecosystem samples. By using remote sensing technologies, we are able to scale up the sample values and supply wall to wall mapping of biomass. Three separate remote sensing technologies are available today to measure ecosystem biomass: passive optical, radar, and lidar. There are many measurement methodologies that range from the application driven to the most technologically cutting-edge. The goal of this book is to address the newest developments in biomass measurements, sensor development, field measurements and modeling. The chapters in this book are separated into five main sections.

\title{
How to reference
}

In order to correctly reference this scholarly work, feel free to copy and paste the following:

Kishore C. Swain and Qamar Uz Zaman (2012). Rice Crop Monitoring with Unmanned Helicopter Remote Sensing Images, Remote Sensing of Biomass - Principles and Applications, Dr. Lola Fatoyinbo (Ed.), ISBN: 978-953-51-0313-4, InTech, Available from: http://www.intechopen.com/books/remote-sensing-of-biomassprinciples-and-applications/rice-crop-monitoring-with-unmanned-helicopter-remote-sensing-images

\section{INTECH}

open science | open minds

\section{InTech Europe}

University Campus STeP Ri

Slavka Krautzeka 83/A

51000 Rijeka, Croatia

Phone: +385 (51) 770447

Fax: +385 (51) 686166

www.intechopen.com

\section{InTech China}

Unit 405, Office Block, Hotel Equatorial Shanghai

No.65, Yan An Road (West), Shanghai, 200040, China

中国上海市延安西路65号上海国际贵都大饭店办公楼 405 单元

Phone: +86-21-62489820

Fax: $+86-21-62489821$ 
(C) 2012 The Author(s). Licensee IntechOpen. This is an open access article distributed under the terms of the Creative Commons Attribution 3.0 License, which permits unrestricted use, distribution, and reproduction in any medium, provided the original work is properly cited. 